Алісва Л. I. Калюжний В. Л. Картамишев Д. О.

Моiсеєва А. М. Сивак P. I.

\title{
ДОСЛІДЖЕННЯ НАПРУЖЕНО-ДЕФОРМОВАНОГО СТАНУ ПОРОЖНИСТИХ ВИРОБІВ ПРИ КОМБІНОВАНОМУ ВИДАВЛЮВАННІ 3 РОЗДАЧЕЮ
}

Процеси холодного видавлювання займають передове місце серед технологій штампувального виробництва завдяки таким перевагам, як висока продуктивність і якість деталей, раціональна витрата матеріалу і різноманіття можливостей формоутворення [1-3]. Розвиток технологій холодного видавлювання пов'язаний з розширенням типу і марок матеріалів штампованих деталей, збільшенням обсягів виробництва точних заготовок, розробкою нових способів формоутворення деталей і нових видів спеціалізованого технологічного обладнання і оснастки.

Поряд з традиційними способами поздовжнього (прямого і зворотного) холодного видавлювання увагу дослідників притягнуто до нових способів поперечного (радіального і бічного) видавлювання та комбінованого поперечно-поздовжнього видавлювання. Розроблена гамма нових способів поперечного, комбінованого поперечно-поздовжнього видавлювання та штампів для їх реалізації. Вони надають можливість отримання порожнистих і суцільних деталей з фланцями і відростками різного перетину, тобто більш складної просторової конфігурації [4-8]. Нові способи видавлювання відрізняються можливістю активного регулювання кінематики течії металу і руху робочого інструменту. Це надає достатню гнучкість процесам видавлювання, поліпшує керування технологічними режимами деформування та якість одержуваних деталей.

Комбінування простих схем (способів) поздовжнього і поперечного видавлювання необхідно для створення більш складних способів деформування, що дозволяють виготовити за одну операцію суцільні і порожнисті деталі з глибокими порожнинами, з фланцями, відростками або інших конфігурацій. Залежно від характеру поєднання простих схем поперечного та поздовжнього видавлювання в одному комбінованому процесі способи підрозділяють на суміщені і послідовні (за часом або за шляхом деформування) способи видавлювання $[4,8,9]$.

У способів послідовного радіально-поздовжнього видавлювання, призначених для отримання порожнистих деталей, можна виділити два основних різновиди схем видавлювання - 3 роздачею металу [7-11] і з обтисненням металу при його радіальному перебігу [12-13].

Схеми видавлювання с витіканням назовні відрізняються послідовним виконанням прийомів радіального та поздовжнього видавлювання. При цьому видавлювання металу відбувається з роздачею, тобто з течією металу від центру заготовки до периферії [5, 9]. У «безматричних» способах видавлювання металу проводитися через бічну поверхню заготовки (рис. 1, схема A1) [6]. Способи видавлювання деталей з суцільної заготовки в результаті розвиненої радіальної течії, що змінюється по ходу прямою (схема А2) або зворотною (схема А3) течією деформованого металу, використовуються відповідно для виготовлення глибоких гільз і стаканів [7, 9-11]. Деформування за даними схемами дозволяє знизити сили штампування за рахунок зменшення площі контакту активного деформуючого інструменту із заготовкою.

Способи радіально-прямого видавлювання групи Б відрізняються тим, що в них радіальне видавлювання металу проводиться в напрямку від периферії до центру (рис. 1, схема Б1). 
Тому їх можна назвати способами послідовного радіально-прямого видавлювання з обтисненням $[8,12,13]$. Залежно від інструменту, що використовується, напрямку металу на етапі прямої течії i, відповідно до ступеня свободи витікання розрізняють кілька схем видавлювання. Для схеми (рис. 1, схема Б2) характерне використання конічного оправлення, здатного до зворотно-поступального переміщення, що необхідне для отримання деталей із змінною товщиною стінки. При профілюванні оправлення (рис. 1, схема Б3) можна виготовляти деталі з оребреною внутрішньою поверхнею, а за умови постачання оправлення незалежним приводом для поздовжнього переміщення та повороту навколо осі можна отримати деталі з профільованою внутрішньою поверхнею $[12,13]$.

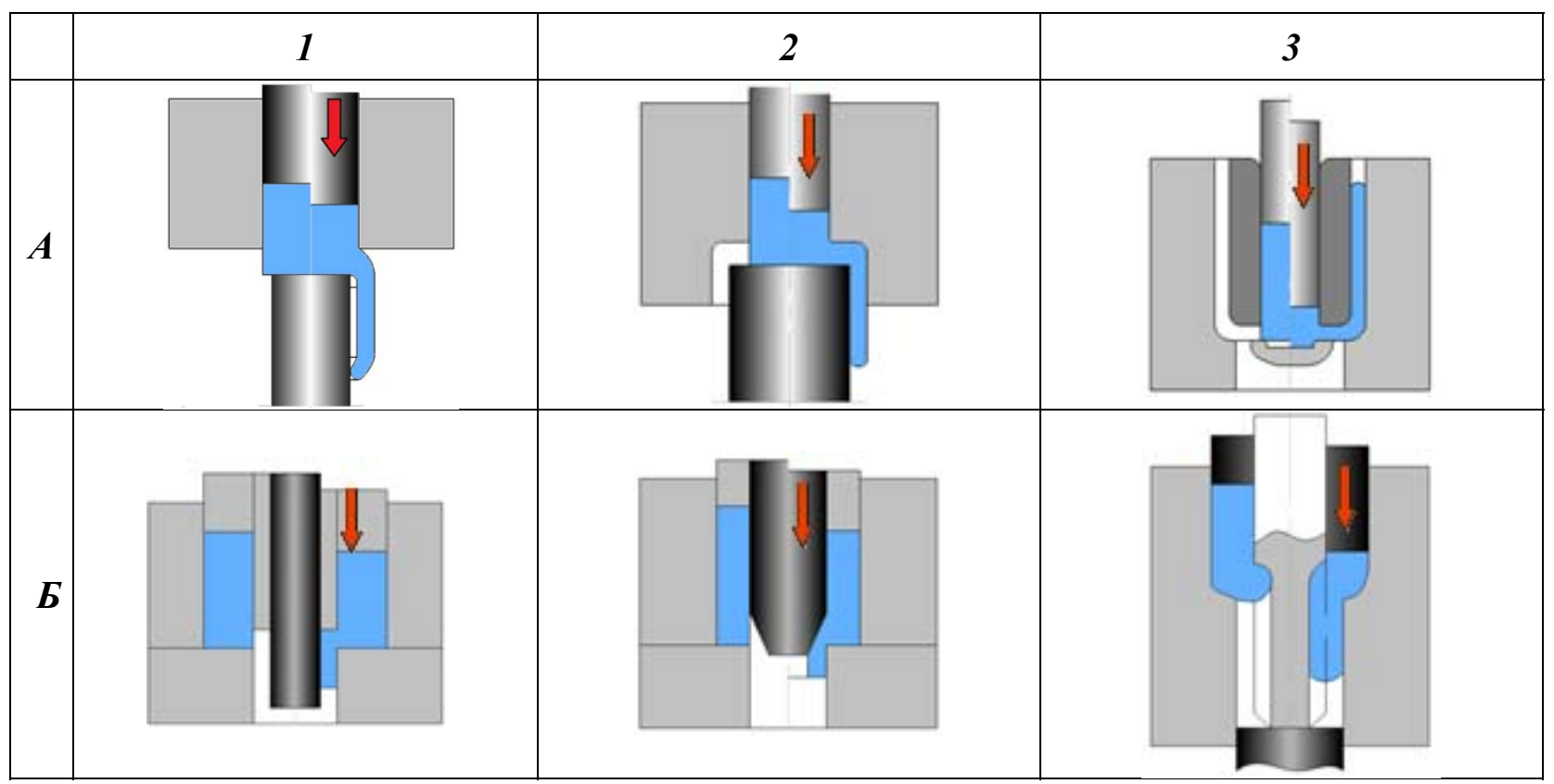

Рис. 1. Способи послідовного радіально-прямого видавлювання

Аналіз силових і деформаційних режимів процесів комбінованого радіальнопоздовжнього видавлювання виконують переважно експериментально, методами скінченних елементів (МСЕ) і верхньої оцінки. Як показано в роботі [10], радіально-пряме видавлювання $\epsilon$ ефективним методом для виробництва виробів типу труб великого діаметру з невеликих циліндричних заготовок. При використанні додаткового гідростатичного тиску в осередку деформації і введенні знакозмінного характеру деформації спостерігається значне збільшення міцності поряд 3 дуже низькою втратою пластичності і високою однорідністю показників твердості деталі. У роботі [14] досліджували вплив деяких важливих конструктивних геометричних параметрів процесу послідовного радіально-прямого видавлювання (товщина фланця, величина кільцевого зазору, радіусу оправлення) на розвиток і коливання навантаження. У роботі [15] представлені силові характеристики процесу послідовного радіальнопоздовжнього видавлювання. Експериментально і скінчено-елементним моделюванням показано вплив конструктивних параметрів, таких як діаметр оправки, радіус матриці і умови тертя на сили деформування.

Для розробки розрахункових залежностей силових і деформаційних параметрів процесів холодного комбінованого видавлювання порожнистих деталей проведені дослідження на основі методів теоретичного аналізу $[1,2]$. Робота [12] містить аналіз силового режиму процесу послідовного радіально-прямого видавлювання порожнистої деталі типу втулки. Методом верхньої оцінки вивчено вплив геометричних параметрів процесу, таких як кут оправлення, величина перекриття і ширина зазору прямої течії, а також умов тертя. Розроблені моделі дозволяють наближено визначити силовий режим деформування, так як прийнято допущення про плоско-деформований стан видавленого зразка. 
Для усунення цих обмежень використовується аналітичний підхід, заснований на визначенні кінематично можливих полів швидкостей (КМПШ) вісесиметричної течії по енергетичному методу балансу потужностей. Для вісесиметричного процесу радіально-прямого видавлювання деталей типу гільз у роботі [16] запропонована модель процесу з використанням найпростіших полів швидкостей паралельної течії, тобто кінематичних модулів (зон) прямокутної форми, які не можуть описати осередок деформації складної конфігурації.

У роботі [17] проведено математичне моделювання силового режиму процесу комбінованого послідовного радіально-прямого видавлювання порожнистих деталей енергетичним методом з використанням модульного підходу, що дозволяє розглянути процес послідовного видавлювання з роздільним аналізом тисків деформування по осередках деформації радіального і прямого видавлювання металу заготовки. Для стадії радіального видавлювання зіставлені різні кінематичні модулі і встановлено переваги трикутних і трапецеїдальних модулів.

Основною метою досліджень методом кінцевих елементів процесу радіальнопоздовжнього видавлювання $[10,11,14.15] \epsilon$ вивчення впливу геометрії інструменту на характеристики напружено-деформованого стану (НДС) порожнистих виробів і зношення інструменту. Загальним обмеженням результатів цих досліджень $є$ відсутність кількісних залежностей для оцінки впливу на показники напруженого стану холодно деформованого металу, умов і параметрів процесу видавлювання, що необхідні для дослідження технологічної деформованості.

Метою даної роботи є дослідження НДС порожнистих деталей в процесі радіальнопрямого видавлювання в залежності від геометричних параметрів і побудова графіків зміни показників НДС на етапах пластичної течії металу.

У даній роботі проводилася оцінка деформованого стану заготовки з латуні BRASSCDA-377 $з$ межею текучості $\sigma_{0,2}=140$ МПа розрахунковим шляхом з використанням програми DEFORM 3D і моделі пружно-пластичного опору деформації матеріалу, що дозволяє встановити точний розподіл нормальних напружень на контактних поверхнях, а також кінцеву форму і розміри штампованих деталей.

Заготовка 1 встановлена в матриці 2 на контрпуансон 3, який розміщений на плиті 4. Видавлювання виконується пуансоном 5 (рис. 2). Формоутворення порожнистих виробів проводили 3 наступними розмірами конструкційних параметрів матриці та пуансону: $R=R_{p}=20 \mathrm{MM}, l=r=2 \mathrm{MM}, \alpha=3^{\circ}, R_{m}=26 \mathrm{MM}, r_{m}=6 \mathrm{MM}, r_{1}=1 \mathrm{MM}, \gamma=60^{\circ}$.

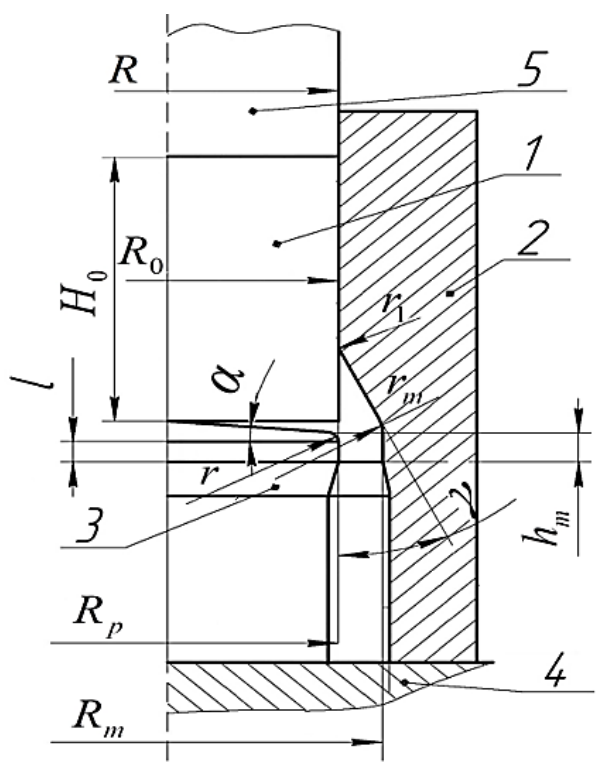

Рис. 2. Розрахункова схема початкової стадії процесу видавлювання з роздачею 
Зміна кута конусної поверхні матриці $\gamma$ в ході процесу радіального-прямого видавлювання з роздачею впливає на силовий режим та розподіл напружень у процесі деформування. Дослідження проводились у діапазоні $17 \ldots 60^{\circ}$. Збільшення кута конусної поверхні матриці призводить до зниження сил деформування на пуансоні при стабільних значеннях на контрпуансоні (рис. 3, а). У свою чергу, максимальні значення нормальних напружень на пуансоні пов'язані зі зменшенням кута конусної поверхні матриці (рис 3, б). Таким чином, матриці з малими кутами необхідні для поліпшеного опрацювання донної частини виробу [18].

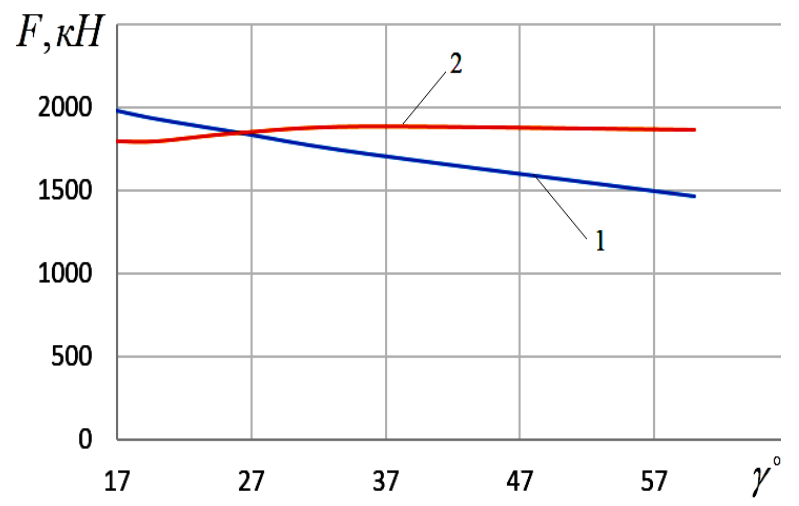

a

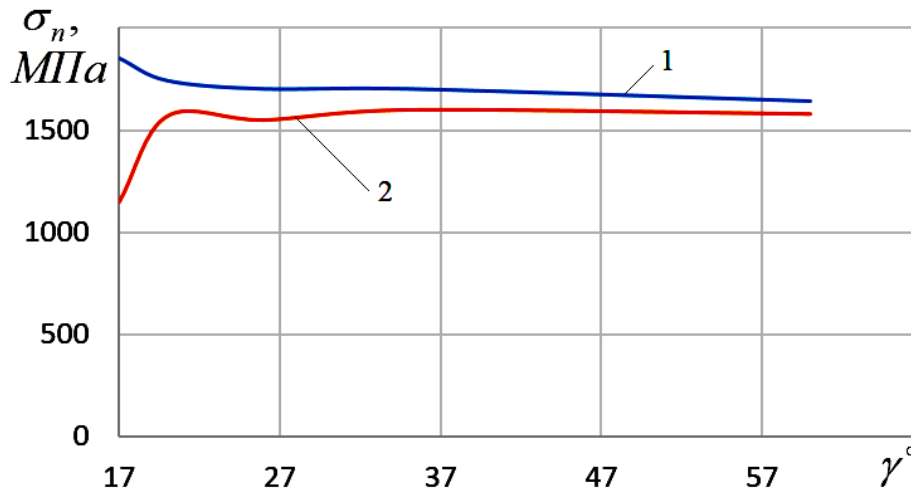

б

Рис. 3. Графіки залежності (а) максимальних сил на пуансоні (1) та контрпуансоні (2) (б), максимальних значень нормальних напружень на пуансоні (1) та контрпуансоні (2) від кута конусної поверхні матриці $\gamma$

Для оцінки показників напружено-деформованого стану заготовки в осередку деформації на послідовних стадіях процесу радіально-прямого видавлювання були обрані 5 характерних точок (P1-P5) в різних досліджуваних зонах заготовки (рис. 4).

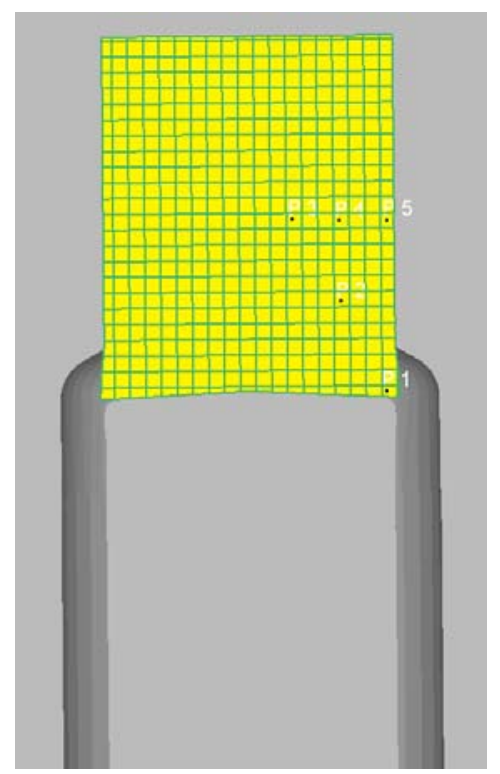

a

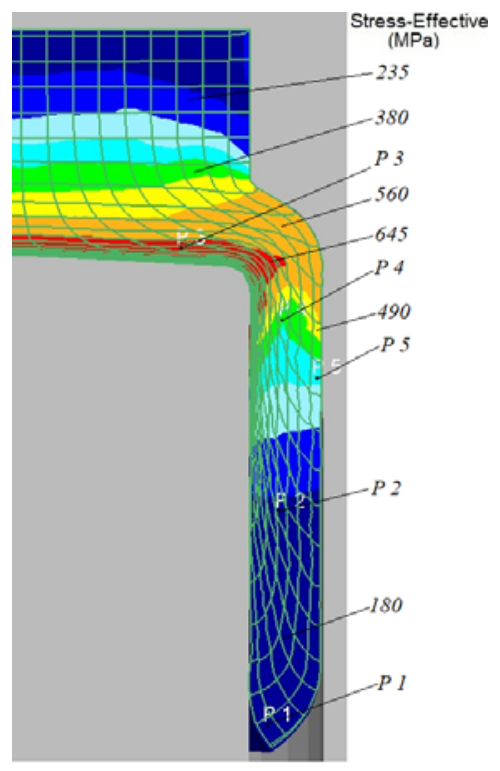

6

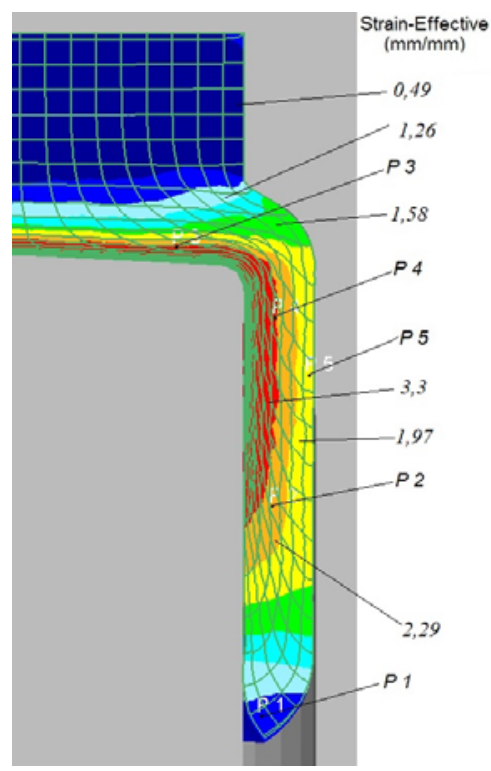

B

Рис. 4. Характерні точки (а) та розподіли інтенсивності напружень $\sigma_{i}$ (б) і інтенсивності деформацій $\varepsilon_{i}$ (в) в осередку деформації 
Для точки P1, яка повністю залишила осередок деформації і розташована в зоні прямої течії металу, інтенсивність напружень істотно менша максимальних величин осередку деформації (рис. 5). Для зони осередку інтенсивної деформації (точки Р2, Р3 і Р4) характерні високі значення інтенсивності напружень, оскільки в даній зоні відбувається зміна напрямку течії металу. Інтенсивність напружень для точки Р5, яка тільки покинула осередок деформації, почала знижуватися. Графіки зміни інтенсивності напружень у міру проходження частинками пластичної зони показують відмінність у розвитку напруженого стану зон, розташованих на бічній поверхні і в центральних областях вихідної заготовки.

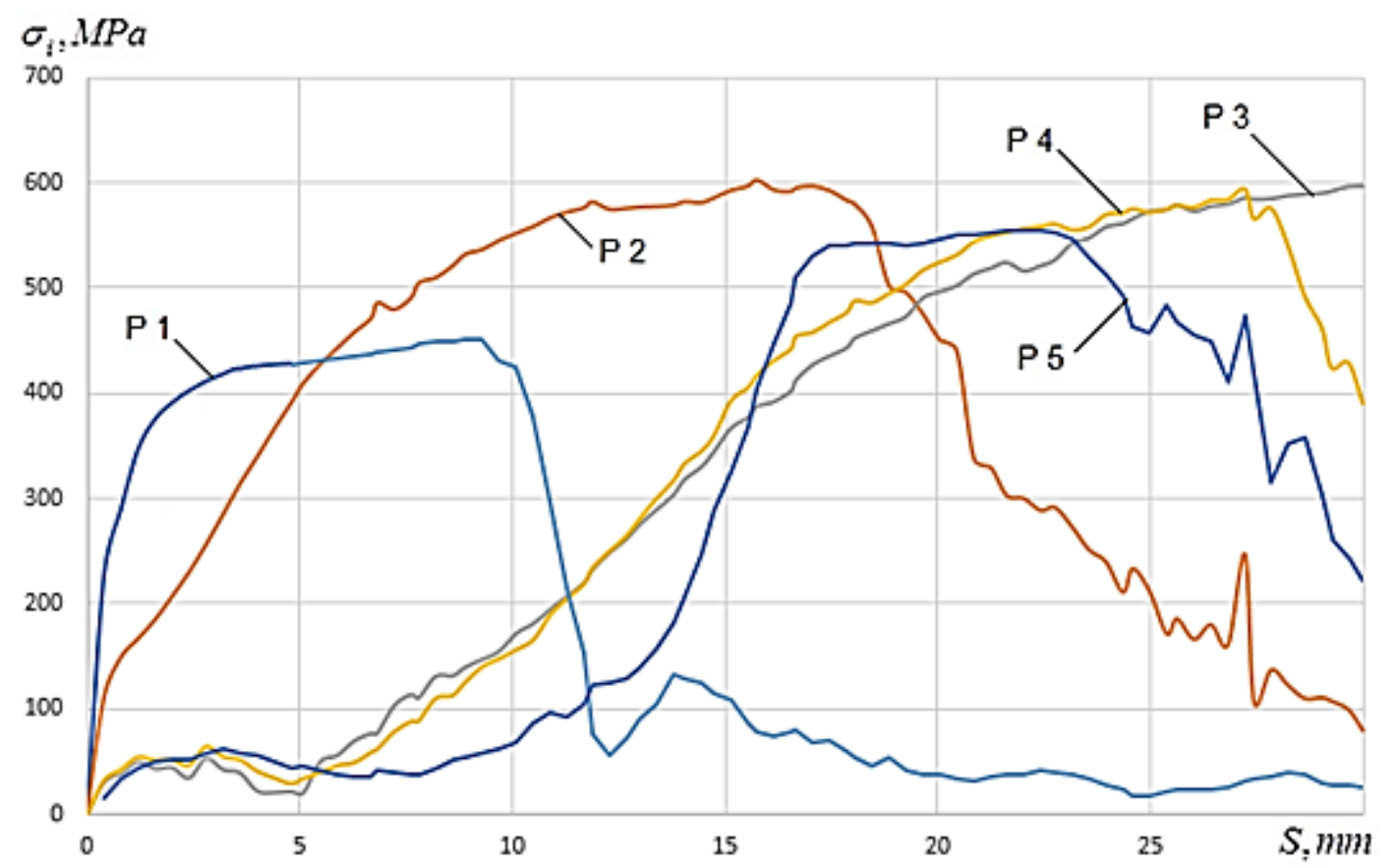

Рис. 5. Інтенсивність напружень в характерних точках осередку деформації

Розподіл інтенсивності деформації відрізняється помітною нерівномірністю. У центральній області найбільш деформовані шари прилягають до дна порожнистого виробу, а найбільшу деформацію набувають внутрішні шари.

Графіки зростання деформацій по ходу процесу видавлювання відображають відмінність у характері накопичення деформацій точками, розташованими в центральних зонах і на бічній поверхні вихідної заготовки (рис. 6).

Інтенсивність деформації точок Р1 і Р2 після проходження матеріальними частинками осередку деформації залишається незмінною. Точка Р2 має більші значення та суттєвіше зростання інтенсивності деформації, бо знаходиться ближче до центральної зони заготовки. До входження в осередок інтенсивного деформування деформація точок Р3-P5 та відповідних їм зон практично непомітна, далі приріст деформації відбувається відносно рівномірно і без стрибків. При цьому більш інтенсивне наростання властиво часткам, розташованим ближче до внутрішньої поверхні порожнини деталі (Р3, Р4).

На діаграмі «Шлях-Сила» відбувається експоненціальне зростання сил видавлювання на пуансоні та контрпуансоні. Зона інтенсивного росту відповідає етапу витікання заготовки від центру до периферії. Незначні підйоми пов'язані зі зміною напрямку течії металу з радіального на прямий. Процес стабілізації графіка відповідає стаціонарній течії металу з утворенням осередку деформації незмінної форми та сталого об’єму (рис. 7). 


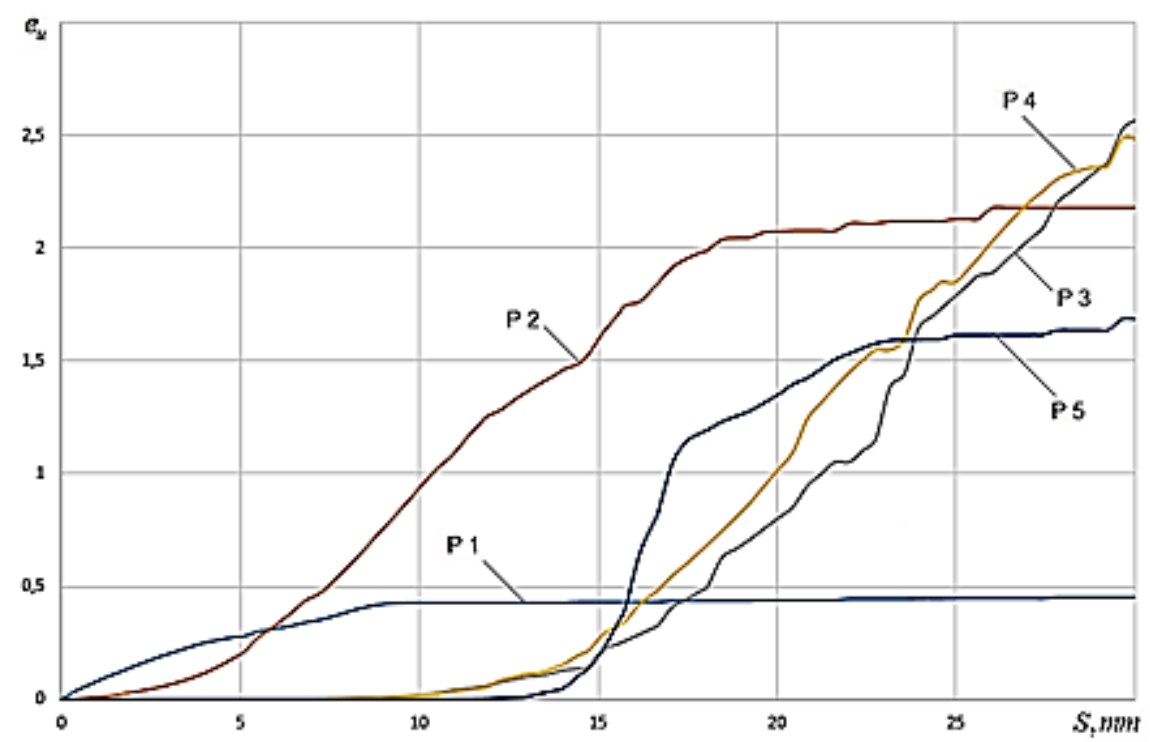

Рис. 6. Зростання інтенсивності деформації характерних точок по ходу процесу видавлювання

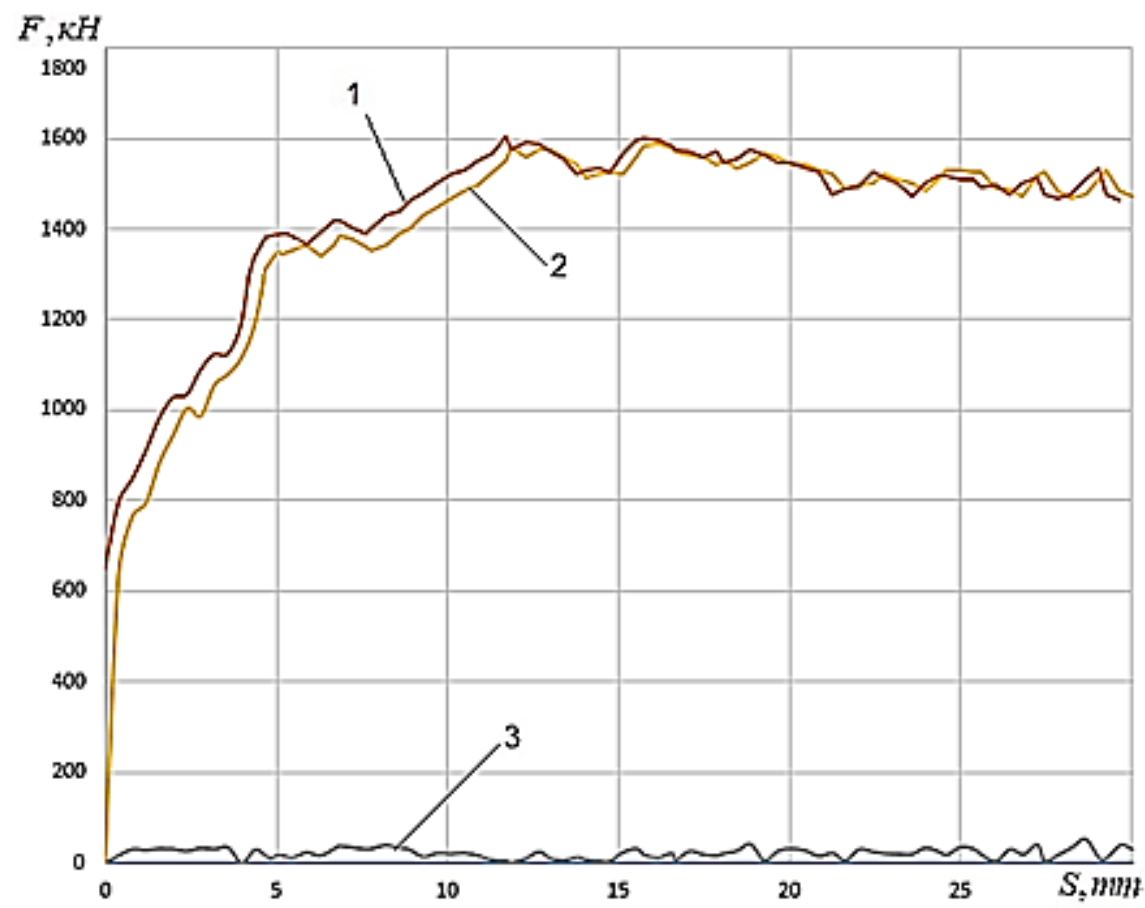

Рис. 7. Графіки зміни сили видавлювання на пуансоні (1), контрпуансоні (2) та матриці (3)

В характерних зонах пластичного деформування для кількісної оцінки характеру зміни напруженого стану визначено показник жорсткості напруженого стану, «шлях деформування», побудований в координатах: інтенсивність деформацій $e_{u}-$ показник напруженого стану $\eta$ (рис. 8).

Значення $\eta$ встановлювали за залежністю [19]:

$$
\eta=\frac{3 \cdot \sigma_{\text {mean }}}{\sigma_{i}}, \sigma_{\text {mean }}=\frac{\sigma_{1}+\sigma_{2}+\sigma_{3}}{3}
$$




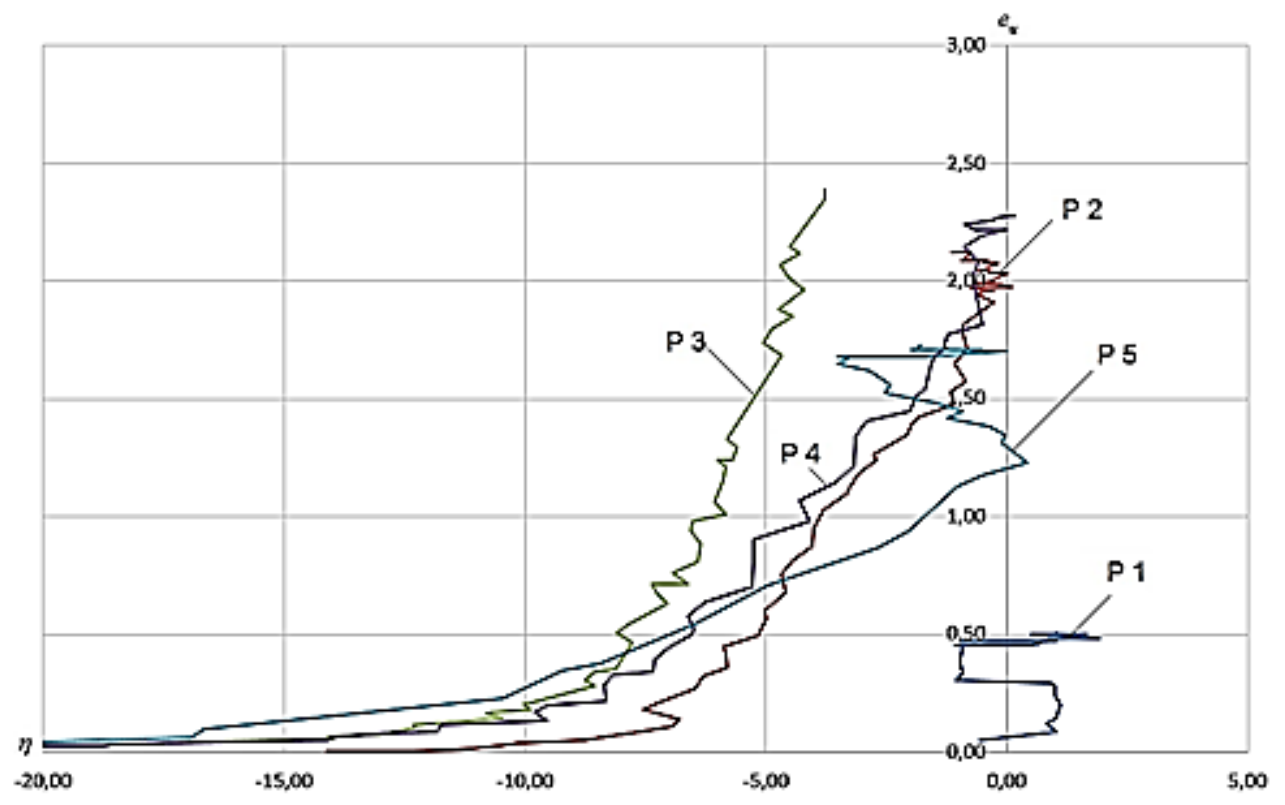

Рис. 8. Графіки залежності інтенсивності деформації від показника напруженого стану для часток Р1-P5

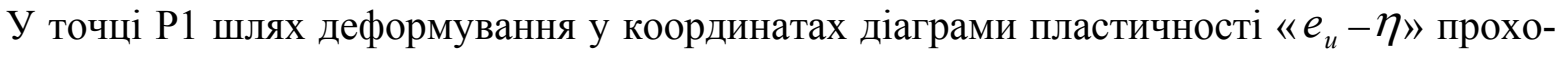
дить через зону з позитивними значеннями показника $\eta$, що свідчить про ймовірність руйнування металу через дії окружних розтягуючих напружень. Це визначення стосується усіх частинок, розташованих на периферії фланця, які формуються на початковій стадії процесу радіального видавлювання. Значення показника напруженого стану для точок P2-P5 розташовані в сприятливій зоні негативних величин. Визначено, що шлях деформування $« e_{u}-\eta »$ розгортається і переходить в більш сприятливу область внаслідок зміни схеми напруженого стану після досягнення кромкою фланця, який видавлюється, зони розвороту металу з радіального напряму на прямий.

У подальшому, частинки (Р3-Р5), що знаходяться у центральній зоні заготовки, не піддаються такій небезпеці руйнування та деформуються більш монотонно, оскільки забезпечені підпором з боку вже сформованої ділянки порожнистого виробу.

\section{ВИСНОВКИ}

Розглянуто різновиди комбінованого видавлювання порожнистих деталей і способи радіально-поздовжнього видавлювання в залежності від напрямку течії металу двома способами: від центру до периферії заготовки та від периферії до центру.

Моделюванням методом кінцевих елементів для схеми видавлювання с роздачею встановлено характер силового режиму та розподілу деформованого стану порожнистих деталей, вивчені закономірності розвитку напружено-деформованого стану заготовок і накопичення деформацій при холодному деформуванні. Встановлено, що зони найбільш інтенсивної деформації прилягають до дна і внутрішньої поверхні порожнини деталі, що матеріальні частинки заготовки, розташовані на периферійних ділянках, піддаються немонотонній деформації з позитивним значенням показника напруженого стану.

Отримано залежності силового режиму і напруженого стану від кута конусної поверхні матриці $\gamma$, що встановлюють форму кінематичних модулів і точніше відображають умови деформування.

Встановлено, що зменшення кута $\gamma$ призводить до збільшення сил деформування на пуансоні, але сприяє поліпшеній обробці донної частини виробу. 


\section{СПИСОК ВИКОРИСТАНОЇ ЛІТЕРАТУРИ}

1. Евстратов В. А. Основы технологии выдавливания и конструирования штампов. Харьков: Вища школа, 1987. 144 с.

2. Овчинников А. Г. Основы теории штамповки выдавливанием на прессах. Москва: Машиностроение, 1983. $200 \mathrm{c}$.

3. Авдеев В. М., Аксенов Л. Б., Алиев И. С. и др. Изготовление заготовок и деталей пластическим деформированием. под ред. К. Н. Богоявленского, В. В. Риса. Ленинград : Политехника, 1991. 351 с.

4. Алиев И. С. Технологические возможности новых способов комбинированного выдавливания. Кузнечно-итамповочное производство. 1990. 2. С. 7-10.

5. Дмитриев А. М., Воронцов А. Л. Выдавливание полых изделий с раздачей заготовки в движущейся матрице. Вестник машиностроения. 2004. 10. С. 55-61.

6. Ренне И. П., Сумарокова А. И. Технологические возможности процесса свободного выдавливания (без матрицы) полых деталей. Кузнечно-итамповочное производство. 1987. 6. С. 25-26.

7. Данилин Г. А., Огородников В. П. Теория и расчеты процессов комбинированного пластического формоизменения. СПб. : БГТУ, 2004. 304 с.

8. Алиева Л.И. Совершенствование процессов комбинированного выдавливания: монография. Краматорск: ООО «Тираж - 51». 2018. 352 с. ISBN 978-966-379-846-2.

9. Алиева Л. И. Процессы комбинированного пластического деформирования и выдавливания. Обработка материалов давлением. 2016. 1 (42). С. 100-108.

10. Jamali S. S., Faraji G., Abrinia K. Hydrostatic radial forward tube extrusion as a new plastic deformation method for producing seamless tubes. The International Journal of Advanced Manufacturing Technology. January 2017. 88. 1-4. pp. 291-301. https://doi.org/10.1007/s00170-016-8754-6.

11. Shatermashhadi M., Sane M. Development of a novel method for the backward extrusion. Materials and Design. 2014. 62, pp. 361-366. http://dx.doi.org/10.1016/j.matdes.2014.05.022.

12. Aliieva L., Zhbankov Y. Radial-direct extrusion with a movable mandrel. Metallurgical and Mining Industry. 2015, 11, pp. 175-183.

13. Murata M., Kuboki T., Kobayashi M., Yamazaki H. Influence of billet material of extruded circular tube with spiral projections on inside wall. Proceedings of the 14th International Conference “Metal Forming - 12”. September 12-19. 2012, Krakow. AGH, pp. 463-466.

14. Jafarzadeh H., Zadshakoyan M., Abdi Sobbouhi E. Numerical studies of some important design factors in radial-forward extrusion process. Materials and Manufacturing Processes. 2010, 25, pp. 857-863.

15. Noh J-h., Hwang Beong-Bok. Numerical analysis of tool geometry effect on the wear characteristics in a radial forward extrusion. Journal of Mechanical Science and Technology. 2015. 29. 8, pp. 3447-3457. https://doi.org/10.1007/s12206-015-0743-4

16. Ebrahimi R., Reihanian M., Moshksar M.M. An analytical approach for radial-forward extrusion process. Materials and Design. 2008, 29, pp. 1694-1700.

17. Алиева Л. И., Картамышев Д. А., Грудкина Н. С., Чучин О. В. Технологические процессы изготовления полых деталей на основе способов комбинированного выдавливания. Обработка материалов давлением. 2018. 1. C. 22-28.

18. Kalyuzhnyi. V. L., Alieva L. I., Kartamyshev D. A., Savchinskii I. G. Simulation of cold extrusion of hollow parts. Metallurgist. 2017. 5-6, pp. 22-27. DOI: https://doi.org/10.1007/s11015-017-0501-1

19. Огородников В. А., Деревенько И. А., Алиева Л. И. Ресурс пластичности металлов при холодном объемном формоизменении : монография. Винница : ООО «Меркьюри-Подолье», 2016. 176 с. ISBN 978-9662696-69-1.

\section{REFERENCES}

1. Evstratov V.A. Fundamentals of extrusion technology and the design of dies. Kharkov: High school. 1987, 144 p. (in Russian).

2. Ovchinnikov A.G. Fundamentals of the theory of stamping by extrusion on the press. Moscow: Mechanical Engineering. 1983, 200 p. (in Russian).

3. Avdeev V.M., Aksenov L.B., Aliiev I.S. et al. The manufacture of blanks and parts by plastic deformation, Eds. Bogojvlensky K.N., Ris V.V. Leningrad: Polytechnic, 1991, 351 p. (in Russian).

4. Aliiev I.S. Technological capabilities of new methods of combined extrusion. Forging and Stamping Production. 1990, 2, pp. 7-10. (in Russian).

5. Dmitriev A.M., Vorontsov A.L. Extrusion of hollow products with the distribution of the workpiece in a moving matrix. Bulletin of mechanical engineering. 2004, 10, pp. 55-61. (in Russian).

6. Renne I.P., Sumarokova A.I. Technological capabilities of the process of free extrusion (without a matrix) of hollow parts. Forging and Stamping Production. 1987, 6, pp. 25-26. (in Russian).

7. Danilin G.A., Ogorodnikov V.P. Theory and calculations of processes of combined plastic forming. SPb: BSTU. 2004,304 p. (in Russian). 
8. Aliieva L.I. Improving the processes of combined extrusion: monograph. Kramatorsk: Ltd "Tiraj - 51". 2018, 352 p. (in Russian).

9. Aliieva L.I. Processes of combined plastic deformation and extrusion. Material Working by Pressure. 2016, 1 (42), pp. 100-108. (in Russian).

10. Jamali S.S., Faraji G., Abrinia K. Hydrostatic radial forward tube extrusion as a new plastic deformation method for producing seamless tubes. The International Journal of Advanced Manufacturing Technology. 2017, 88, 14, pp. 291-301. DOI: https://doi.org/10.1007/s00170-016-8754-6

11. Shatermashhadi M., Sane M. Development of a novel method for the backward extrusion. Materials and Design. 2014. Volume 62, pp. 361-366. DOI: http://dx.doi.org/10.1016/j.matdes.2014.05.022

12. Aliieva L., Zhbankov Y. Radial-direct extrusion with a movable mandrel. Metallurgical and Mining Industry. 2015, 11, pp. 175-183.

13. Murata M., Kuboki T., Kobayashi M., Yamazaki H. Influence of billet material of extruded circular tube with spiral projections on inside wall. Proceedings of the 14th International Conference "Metal Forming - 12". Sept. 12-19. 2012, AGH. Krakow, pp. 463-466.

14. Jafarzadeh H., Zadshakoyan M., Abdi Sobbouhi E. Numerical studies of some important design factors in radial-forward extrusion process. Materials and Manufacturing Processes. 2010, 25, pp. 857-863.

15. Noh J-h., Hwang Beong-Bok. Numerical analysis of tool geometry effect on the wear characteristics in a radial forward extrusion. Journal of Mechanical Science and Technology. 2015, 29, 8, pp. 3447-3457. DOI: https://doi.org/10.1007/s12206-015-0743-4.

16. Ebrahimi R., Reihanian M., Moshksar M.M. An analytical approach for radial-forward extrusion process. Materials and Design. 2008, 29, pp. 1694-1700.

17. Aliieva L.I., Kartamyshev D.A., Grudkina N.S., Chuchin O.V. Technological processes for the manufacture of hollow parts based on the methods of combined extrusion. Material Working by Pressure. 2018, 1, pp. $22-28$. (in Russian).

18. Kalyuzhnyi. V.L. Aliieva L.I., Kartamyshev D.A., Savchinskii I.G. Simulation of cold extrusion of hollow parts. Metallurgist. 2017, 5-6/2017, pp. 22-27. DOI: https://doi.org/10.1007/s11015-017-0501-1

19. Ogorodnikov V.A., Derevenko I.A., Aliieva L.I. Resource of plasticity of metals during cold volumetric shaping: monograph. Vinnitsa: VNTU, Ltd “Mercury-Podillia”. 2016, 176 p. (in Russian).

Алієва Л. І. - д-р техн. наук, доцент ДДМА;

E-mail: omd@dgma.donetsk.ua;

Калюжний В. Л. - д-р техн. наук, проф. каф. МПМ та РП НТУУ «КПІ»;

Картамишев Д. А. - - асистент ДДМА;

Моісєєва А. М. - - аспірант ДДМА;

Сивак Р. I. - - - д-р техн. наук, доцент ВНАУ.

ДДМА - Донбаська державна машинобудівна академія, м. Краматорськ.

НТУУ «КПІ»- Національний технічний університет України «Київський політехнічний інститут», м. Київ.

ВНАУ - Вінницький національний аграрний університет, м. Вінниця. 